\title{
Poverty and Migration in Western Balkan Countries
}

Emi Malaj

PhD Cand. University of Vlora, Faculty of Economy, Department of Economics

Visar Malaj

$\mathrm{PhD}$, University of Tirana, Faculty of Economy, Department of Economics

\begin{abstract}
According to Lee (1966), the number of immigrants in a specific country is positively related with the level of the corresponding diversity of areas and people. Negative economic conditions in origin countries lead to the increase of migration flows; as a consequence, we find high immigrant volumes in wealthier countries and a significant level of mobility in least developed countries. Every stream provokes a counterstream: a relevant part of immigrants return to their home country, due to possible future economic recessions or to the learning or developing particular skills. Dissimilarity between countries and strong immigration barriers reinforce the counterstream effect. We analyze in this paper the link between poverty and migration in Western Balkan countries, and the respective implications for reforms and policies. The number of Western Balkan citizens who emigrate to developed European countries has dramatically increased over the past years. This is a consequence of increasing unemployment, poverty and social inequality. We also estimate a particular econometric model, including different experimental variables, related with migration and poverty.
\end{abstract}

Keywords: poverty, migration, Western Balkans.

\section{Introduction}

\section{Facts and figures}

Western Balkan (WB) region includes Kosovo, Albania, Croatia, Montenegro, Serbia, Bosnia and Herzegovina and Macedonia. Croatia is not included in this group in the recent scientific studies and reports, mainly due to the economic gap with the other countries. Croatia is the only WB country which is actually part of the European Union (EU), since July 2013. The number of WB emigrant has dramatically increased over the past years. The largest groups originate from Albania, Kosovo and Serbia. This phenomenon is a consequence of increasing social inequality and poverty. Table 1 shows the population living below income poverty line and percentage of the population living below the international poverty line \$1. 25 a day for five WB countries.

\begin{tabular}{|l|l|l|}
\hline $\begin{array}{l}\text { Population living below income } \\
\text { poverty line(\%) }\end{array}$ & National poverty line & PPP \$1.25 a day \\
\hline Country & $2004-2014$ & $2002-2012$ \\
\hline Albania & 14,3 & 0,5 \\
\hline Bosnia and Herzegovina & 17,9 & 0,0 \\
\hline Montenegro & 11,3 & 0,2 \\
\hline Serbia & 24,6 & 0,1 \\
\hline FYROM & 27,1 & 0,3 \\
\hline
\end{tabular}

Table 1. Population living below income poverty line and percentage of the population living below the international poverty line $\$ 1.25$ (in purchasing power parity terms) a day for five Western Balkan countries. Source: Authors' Elaboration on United Nations Data. 
Albania signed the Stabilisation and Association Agreement (SAA) with the EU in June 2006, which entered into force in April 2009. Albanian citizens can travel without a visa to the Euro area since December 2010. In June 2016, the EU countries granted Albania the candidate status. The most important European destinations for Albanian migrants are Italy, Greece and Germany. The number of Albanian nationals who resided in Germany was 24. 00010 in 2014. In 2013, there were 465. 000 Albanian nationals who resided in Italy12. The total number of Albanian nationals who reside in Greece is more than 600.000.

In November 2007, the Serbian government signed the SAA with the EU, which entered into force in September 2013. Serbian citizens can travel without the need for visas to the Euro area since December 2009. In March 2012, Serbia obtained the candidate status and in January 2014, the European Council initiated the official accession negotiations. The recognition of the independence of Kosovo is an unsolved problem for Serbia an important obstacle to the EU membership. Germany and Austria are the countries with the greatest number of Serbians in Europe. The German residents with Serbian background were about 305. 000 in 2014. In 2015, the number of Serbian nationals who reside in Austria was about 114. 000 .

In 2004, the SAA between EU and the Former Yugoslav Republic of Macedonia entered in force. In 2005, the European Commission accorded the candidate status to Macedonia, fourteen years after the declaration of independence from ExYugoslavia. In 2009, Macedonians obtained the right to travel without the need for visas to the Euro area. In 2012, the European Commission initiated a High-Level Accession Dialogue with the Macedonian authorities in 2012, a contribution to the acceleration of public administration and electoral reforms, the protection of minorities' rights, the promotion of market competition and economic growth. The naming disagreement with Greece is an important obstacle for the accession of Macedonia to the EU. Greek authorities consider 'Macedonia' a Greek term, connected with an ancient Greek region. Greece would exercise its veto right to obstruct the Macedonia's membership to the EU, if this problem remains unresolved. Macedonian road to EU is also conditioned on the difficult relations with Bulgarian authorities, who have expressed their indignation against the distortion of history between the two countries. The protection of Albanian minority rights is another problem, correlated with the accession of Macedonia to the EU. Albanians should enjoy equal rights and equal opportunities as Macedonians. The largest communities of Macedonians live in Germany, Italy and Switzerland. There were 77. 000 Macedonian citizens living in Italy in 2013. The number of Macedonian citizens in Germany was 83. 00010 in 2014. There were 63. 000 Macedonian citizens living in Switzerland in 2013.

Bosnian citizens can travel to the Euro area without a visa since December 2010. EU and Bosnia and Herzegovina started the High-Level Dialogue on the Accession Process in 2012. The SAA between Bosnia and Herzegovina and the EU entered into force in 2015. Germany and Austria are two of the most important destinations for the emigrants of Bosnia and Herzegovina. There were 164. 000 Bosnian nationals who resided in Germany in 201410. The number of Bosnian nationals who resided in Austria was 93. 000 in 201511.

Montenegro is an independent state since the dissolution of the Union of Serbia and Montenegro after the referendum of May 2006. Montenegro reopened new accession negotiations with the EU and signed the SAA in 2007, which entered into force in May 2010. Montenegrins can travel without visa to the Euro area since December 2009. After the 2010 favourable opinion of the European Commission regarding the application for EU membership, Montenegro initiated the accession negotiations in 2012. Germany and Switzerland are the most important West European destinations for Montenegrin emigrants. In 2014, there were 2. 500 Montenegrins who resided in Switzerland in 201413. The number of Montenegrin migrants for the this year in Germany was 20. 00010.

Kosovo is a potential candidate for the accession to the EU. The Assembly of Kosovo declared independence in an extraordinary session in 2008. The number of United Nations member states which have already recognized Kosovo's independence was 113 in November 2016; of these, 23 countries are members of the EU. The USA and the EU have assisted Kosovo and its authorities in the road to the economic progress and in the consolidation of the rule of law. Most of the EU countries have their diplomatic offices and embassies in Kosovo. In 2015, Kosovo signed the SAA with the EU, an important incentive for the implementation of reforms. In Germany and Switzerland, we can find the largest communities of Kosovars. In 2014, the number of Kosovar citizens who resided in Germany and in Switzerland was respectively, 185. 00010 and 100. 00013. 


\section{Literature review}

According to Lee (1966), factors which help or obstruct migration can be marked with respectively, positive and negative signs. For example, a better climate affect positively migration into a certain country and vice versa. Negative economic conditions in origin countries lead to the increase of migration flows; as a consequence, we find high immigrant volumes in wealthier countries and a significant level of mobility in least developed countries. According to Lee (1966), migrants move generally through known bilateral routes, such as the movement of Sicilian immigrants to the Northern United States cities. Every stream provokes a counterstream: a relevant part of immigrants return to their home country, due to possible future economic recessions or to the learning or developing particular skills. Dissimilarity between countries and strong immigration barriers reinforce the counterstream effect.

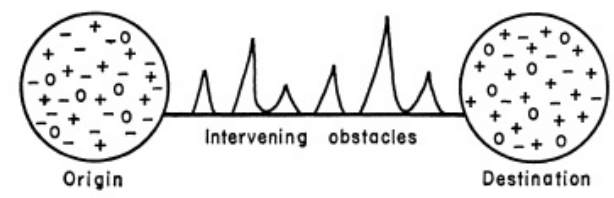

\section{Figure 1. The migration process. Source: Lee, 1966.}

The author also focused on migrants characteristics. Migrants from a specific origin country are not a good sample of the corresponding population, due to different ways of adaption to host countries factors. Successful people in origin countries are more likely to respond positively to destination country factors and vice versa. Other relevant individual variables like sex, age, education, profession, size of family and marital status can stimulate or prevent migration. Lewis (1954) developed for the first time a model for forecasting migration flows, based on a neoclassical macroeconomic approach. This is known as the dual-sector model and consists of two sectors, an urban sector that is public or private, and characterized by a high marginal productivity of labour, and a rural or subsistence sector, with very low marginal productivity of labour. The rural, less developed sector is made up of self-employed and informal jobs, where wages and productivity are low, while the urban and developed sector is governed by the industrialists who offer jobs in factories, plantations, etc., that provide high wages. Wages and income differences, and the enlargement of the developed sector stimulate the emigration from the rural sector. Workers migration will continue as long as the difference in labour demand is zero, and as a consequence, total labour productivity will increase. Ranis and Fei (1961) extended Lewis (1954) model for developing countries, and took into account the Rostow (1960) stages of economic growth, particularly the 'take-off' period, which lasts 20 or 30 years and it is characterized by an increase of urban population and industrial progress, mainly caused by workforce growth. They evaluated the effects of emigration from the rural (agricultural) areas to the fast growing urban (industrial) sector on wages and total production. The authors argued that these sectors are particularly related to each other. The immigrants employment will encourage productivity and investments in the urban (developed) sector. The 'gap' created by the movement of people may be exploited to help the progress of the rural (less developed) sector, so as a consequence, future policies should encourage investments and economic growth in both economic sectors. According to Harris and Todaro (1970), earning differences and urban unemployment are two relevant factors of movement from rural to urban areas. People will migrate only if the expected urban income is significantly greater than the rural (agricultural) product. The variables of employment and wages in the developed sector are positively related with the urban income. Labour productivity in the less developed sector and the corresponding wages and income are also in a direct relation. Individuals will migrate from one sector to the other until equilibrium between expected real wage in the developed sector and agricultural real wage is reached. A rural income growth will stimulate backward migration. This means that labour opportunity cost in the developed sector is higher than in the rural sector. Harris and Todaro (1970) argued that policies oriented towards wage subsidies and barriers to migration will contribute to the economic growth of both sectors. According to Piore (1979), international labour migration is generally affected by pull factors. Developed countries are characterized by a dual labour market: a principal market that is composed of stable and lucrative jobs for domestic workers, and a less developed market of precarious and unqualified jobs that are carried out by immigrants. Both the low wages and the existence of a considerable number of immigrants, lead to the refusal of these jobs from domestic workers. They are attracted by a better prospective and higher wages, which are achievable in the principal market. This approach is rather superficial for the reason that it considers a single pull variable and do not include other possible factors of migrant flows. Mabogunje (1970) developed the General Systems approach to analyze migration. In this analysis, migration is considered 
as a dynamic process, characterized by continuous changes over an infinite period of time. The author also took into account the spatial aspect of migration: rural-urban movements may alter significantly the society composition. People often migrate from less developed areas to big industrialized cities. According to this model, the decision to migrate in developed areas is largely influenced by the institutions, the so-called sub-systems, and other different factors.

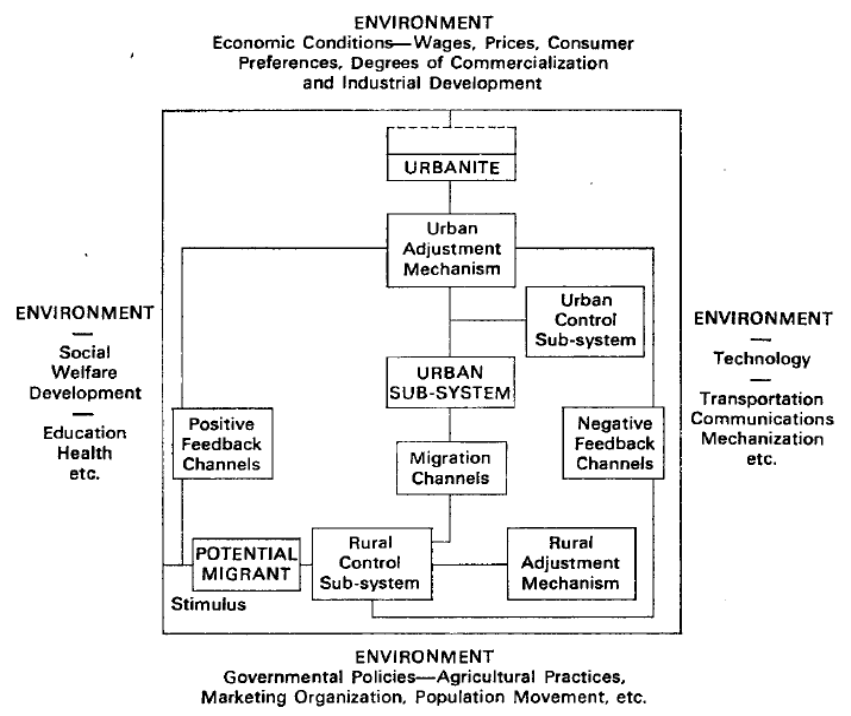

Figure 2. Theory of rural-urban migration. Source: Mabogunje, 1970.

The most important rural sub-system is the family and the society. Urban sub-systems (agencies and government) can help or obstruct people movement. The model includes other possible factors that affect the decision of a potential migrant such as the environment (which can transmit negative or positive signals), and the information from existing immigrants. Borjas (1994) analyzed the contribution of immigrants to countries economy and on the efficiency of immigration policies. Highly skilled foreign immigrants, and well-integrated into the labour market, have a positive impact on economic growth and contribute to the reduction of wage differences between foreign and domestic workers. Foreigners that have been living in the U. S. for over 20 years earn more than natives, despite the modest influence of immigrants on wages of native workers. Goss and Lindquist (1995) considered different approaches for the study of labour migration, focusing on the network theory. The authors took into account a vast network of mediators, which objective is to maximize their individual profit. They also operate as institutional agents helping in the implementation of regulations and in the achievement of certain balances. Regardless of this contribute, mediators can often affect negatively migrant selection.

Guilmoto and Sandron (2001) analyzed rural-urban labour migration in developing countries. They considered migration as an institution, in order to identify the routes and networks that contribute in people movements. The authors included in their analysis some particular aspects of the society such as regulations, traditions, values and principles. Networks are infrastructures that encourage migration and help to determinate the potential destinations and intervals of stay. They also decrease transaction costs and facilitate the integration in the destination country. The endogenous features of networks can also inhibit people movements. Hatton and Williamson (2011) considered the life cycle of emigration to the U. S. from five major areas: Asia, Latin America, North Africa, Middle East, Sub-Saharan Africa. The authors tested some supply and demand side variables, and confirmed the significant correlation between the decision to migrate and poverty, education, demographic transition and migration stock.

\section{Empirical results}

We analyze some of the WB migration factors, considered in micro and macro theories of migration in an extended gravity model. We estimate two different equation, basic and experimental. The basic equation includes the populations of origin and destination countries, and the corresponding distances. The experimental equation also includes the GDPs per capita 
and the unemployment rates of both home and host countries. The following table shows the definition and the expected signs for the considered variables.

\begin{tabular}{|l|l|l|}
\hline Variable & Definition & Expected sign \\
\hline mig_odt & Migration stock in destination d from origin o at year t & Dependent variable \\
\hline gdpcap_ot & GDP per capita in origin o at year t & - \\
\hline pop_ot & Population in origin o at year t & + \\
\hline gdpcap_dt & GDP per capita in destination d at year t & + \\
\hline pop_dt & Population in destination d at year t & + \\
\hline dist_od & Bilateral distance & - \\
\hline unemp_diff_odt & Difference between unemployment rates in origin o and destination d & + \\
\hline
\end{tabular}

\section{Table 2. Definition and expected sign of considered variables.}

We have estimated the equations for a specific dataset which includes WB migration stock in the principal European destinations for the time period 2010-2015. Eurostat and OECD (Organisation for Economic Co-operation and Development) were our main sources for migration data. GDPs and the respective populations were obtained from the World Bank database. Bilateral distances were sourced from the CEPII GeoDist database (Mayer dhe Zignago, 2011). Unemployment rates data were obtained from Eurostat and the World Bank.

Random effects resulted the most apropriate estimation method. This is a particular case of the fixed effects model, where we assume that the unobserved heterogeneity is stable over time and correlated with the explanators. The following table shows the estimation results for the formulated equations. Variables are expressed in the natural logarithmic form. Coefficents signs are always according to the initial expectations. Parameters are statistically significative, so we confirm the relevance of the considered variables for migration stocks. The adjusted R-squared are relatively high, so our factors expain a relevant proportion of the variability of the dependent variable. The coefficient values are comparable to past similar studies (e. g. Pedersen, Pytlikova and Smith, 2008; Ortega and Peri, 2013).

\begin{tabular}{|l|l|l|}
\hline $\begin{array}{l}\text { Independent } \\
\text { variable }\end{array}$ & $\begin{array}{l}\text { Basic } \\
\text { equation }\end{array}$ & $\begin{array}{l}\text { Extended } \\
\text { equation }\end{array}$ \\
\hline Intercept & $6,451(0,0011)$ & $4,943(0,0038)$ \\
\hline gdpcap_o & & $-1,351(0)$ \\
\hline pop_0 & $1,093(0)$ & $1,853(0)$ \\
\hline gdpcap_d & & $1,285(0,009)$ \\
\hline pop_d & $1,013(0,004)$ & $1,17(0,002)$ \\
\hline Dist & $-2,284(0)$ & $-2,352(0)$ \\
\hline unemp_diff & & $0,704(0)$ \\
\hline $\begin{array}{l}\text { Adjusted } \\
\text { R-squared }\end{array}$ & 0,616 & 0,657 \\
\hline
\end{tabular}

Table 3. Estimation results (coefficents and the corresponding $p$-values).

\section{Concluding remarks}

Migration is considered as a dynamic process, characterized by continuous changes over an infinite period of time. Wages and income differences, and the enlargement of the developed areas stimulate the emigration from the less developed countries. Negative economic conditions in origin countries lead to the increase of migration flows from the WB to developed European countries. Other relevant individual variables like sex, age, education, profession, size of family and marital status 
can stimulate or prevent migration. We estimated in this paper two particular equations for WB migration stocks. According to the results, poverty and unemployment also stimulate emigration from WB countries.

The immigrant's employment will encourage productivity and investments in the developed countries. The 'gap' created by the movement of people may be exploited to help the progress of the less developed countries, so as a consequence, future policies should encourage investments and economic growth in both countries. Developed countries are characterized by a dual labour market: a principal market that is composed of stable and lucrative jobs for domestic workers, and a less developed market of precarious and unqualified jobs that are carried out by immigrants. Both the low wages and the existence of a considerable number of immigrants, lead to the refusal of these jobs from domestic workers. They are attracted by a better prospective and higher wages, which are achievable in the principal market. Highly skilled foreign immigrants, and well-integrated into the labour market, have a positive impact on economic growth and contribute to the reduction of wage differences between foreign and domestic workers.

\section{References}

[1] Beine, M., Bertoli, S., \& Moraga, J. (2015). A practitioners' guide to gravity models of international migration. The World Economy, 1-17.

[2] Borjas, G. (1994). The economics of immigration. Journal of Economic Literature, 32(4):1667-1717.

[3] Clark, X., Hatton, T., \& Williamson J. (2007). Explaining U. S. Immigration, 1971-1998. The Review of Economics and Statistics, 89(2), 359- 373.

[4] Goss, J., \& Lindquist, B. (1995). Conceptualizing international labour migration: a structuration perspective. International Migration Review 29(2): 317-351.

[5] Grogger, J., \& Hanson, G. (2007). Income maximization and the sorting of emigrants across destinations. Mimeo, UCSD.

[6] Grogger, J., \& Hanson, G. (2008). Income maximization and the selection and sorting of international migrants. Working Paper 13821, NBER.

[7] Grogger, J., \& Hanson, G. (2011). Income maximization and the selection and sorting of international migrants. Journal of Development Economics, 95(1), 42-57.

[8] Guilmoto, C., \& Sandron, F. (2001). The internal dynamics of migration networks in developing countries. Population: An English Selection 13(2): 135- 164.

[9] Harris, J., \& Todaro, M. (1970). Migration, unemployment, and development: a two-sector analysis. American Economic Review 60: 126-142.

[10] Head, K., \& Mayer, T. (2014). Gravity equations: workhorse, toolkit, and cookbook. Handbook of International Economics Vol.2, eds. Gopinath, Helpman, and Rogof.

[11] Kim, K., \& Cohen, J. (2010). Determinants of international migration flows to and from industrialized countries: a panel data approach beyond gravity. International Migration Review, 44(4), 899-932.

[12] Lee, E. (1966). A theory of migration. Demography, 3: 47-57.

[13] Lewis, W. (1954). Economic development with unlimited supplies of labor. Manchester School of Economic and Social Studies, Vol. 22, pp. 139-91.

[14] Mabogunje, A. (1970). Systems approach to a theory of rural-urban migration. Geographical Analysis 2: 1-18.

[15] Mayer, T., \& Zignago. S. (2011). Notes on CEPIl's distances measures: The GeoDist Database. CEPII Working Paper 25.

[16] Ortega, F., \& Peri, G. (2009). The causes and effects of international migrations: evidence from OECD countries 1980-2005. Working Paper 14833, National Bureau of Economic Research.

[17] Ortega, F., \& Peri, G. (2013). The effect of income and immigration policies on international migration. Migration Studies, 1(1), 47-74.

[18] Pedersen, P., Pytlikova, M., \& Smith, N. (2008). Selection and Network Effects. Migration flows into OECD countries 1990-2000. European Economic Review, 52(7), 1160 - 1186.

[19] Piore, M. (1979). Birds of passage: migrant labor in industrial societies. Cambridge: Cambridge University Press.

[20] Ranis, G., \& Fei., J. (1961). A theory of economic development. American Economic Review 51: 533-565.

[21] Hatton, T. J., \& Williamson, J. G. (2011). Are third world emigration forces abating?. World Development, 39(1), 20-32.

[22] Rostow, W. (1960). The stages of economic growth: a non-communist manifesto. Cambridge University Press. 